\title{
Modelowanie geostatystyczne w wyznaczaniu przestrzennego rozkładu parametrów petrofizycznych utworów ilasto-mułowcowych
}

\section{Geostatistics modeling in determining the spatial distribution of petrophysical parameters of claystone and mudstone formations}

\author{
Tadeusz Kwilosz \\ Instytut Nafty i Gazu - Państwowy Instytut Badawczy
}

\begin{abstract}
STRESZCZENIE: W związku ze zmniejszającymi się zasobami gazu w złożach zlokalizowanych w utworach piaskowcowych i skałach węglanowych coraz większym zainteresowaniem cieszą się obiekty strukturalne związane z utworami piaskowcowo-mułowcowo-łupkowymi ulokowane w utworach miocenu. Złoża te charakteryzują się dużą zmiennością facjalną tych utworów, w tym wyklinowaniem się lamin i warstewek. W związku z powyższym porowatość oznaczona dla tych skał nie może być liczona do bilansu porowatości efektywnej, służącej do oszacowania zasobów wydobywalnych. Obliczając miąższość efektywną, powinno się pominąć miąższość skał łupkowych. Jednym z zasadniczych problemów, będących przedmiotem tego opracowania, jest wydzielenie miąższości skał należących do poszczególnych typów litologicznych. W celu rozpoznania zmienności litologicznej tego typu skał użyto pomiarów profilowania gamma. Należy jednak podkreślić, że ze względu na bardzo małą miąższość warstw piaskowcowych i mułowcowych nie są one możliwe do jednoznacznej identyfikacji za pomocą profilowania gamma. Profilowanie gamma wskazuje raczej wartości uśrednione w obrębie pomiaru niż konkretne warstwy. W związku z tym dokonano oszacowania procentowego udziału miąższości każdego z typów litologicznych w całkowitej miąższości struktury przewierconej przez każdy odwiert. Podział taki przeprowadzono za pomocą analizy rozkładów empirycznych pomiarów gamma. Założono, że niejednorodności litologiczne uwidocznią się na wykresach histogramów w formie rozkładów wielomodalnych lub wyraźnych zmian monotoniczności. Dane te posłużyły do wygenerowania przestrzennych rozkładów parametrów na siatce modelu w punktach nieobjętych pomiarem. Użyto do tego celu metody krigingu zwyczajnego oraz krigingu z trendem. Przy zastosowaniu tych samych metod interpolacyjnych wygenerowano mapy stropu i spągu modelu badanego złoża. Korzystając z wyników pomiarów porowatości, dokonano przyporządkowania wyniku tych pomiarów do wydzielonych wcześniej typów litologicznych. Dla każdego typu skały i przy użyciu obydwu metod krigingu wyznaczono rozkład porowatości w punktach siatki modelu złoża. Do oszacowania niepewności uzyskanych wyników posłużono się metodą kroswalidacji. Na zakończenie obliczono objętość porów efektywnych modelu złoża, zakładając, że tylko skały piaskowcowe i mułowcowe są źródłem porów efektywnych. Oszacowano niepewność uzyskanego wyniku. Na rzecz opracowania posłużono się rzeczywistymi danymi z pomiarów geofizycznych dla złoża w utworach miocenu.
\end{abstract}

Słowa kluczowe: kriging, kroswalidacja, porowatość efektywna.

ABSTRACT: Due to decreasing gas reserves in deposits found in sandstone $\mathrm{f}$ and carbonate formations, geological structures composed of mudstone and shale layers found in Miocene formations are growing in popularity. These deposits are characterized by high facial variability. Shale rocks have very low permeability. Therefore, the porosity determined for these rocks cannot be taken into account in the balance of the effective porosity used to estimate the natural gas reserves. Shale rock thickness should be excluded when calculating effective thickness of the gas bearing formations. The main problem of this study is the proper separation of the rocks belonging to individual lithological facies. Gamma ray logs were used to identify lithological variability of this type of rock. It should be emphasized, however, that due to the very low thickness of sandstones and mudstones, it was not possible to identify them clearly using the archival gamma ray logs. The archival gamma ray logs indicate the average values of the layer rather than that of specific laminas, because of its measurement resolution. Therefore, an estimation was made in order to calculate the percentage share of the thickness of each lithological type in the total layer thickness in each well. This division was made using the analysis of empirical distributions of gamma ray logs. It was assumed that lithological heterogeneities would be visible on experimental histograms in the form of multimodal distributions or clear changes in monotonicity. These data were used to generate a spatial distribution of parameters on the model grid at points not covered by the measurement. For this purpose, the ordinary kriging method and the kriging with trend method were used. Using the same interpolation methods, the structure maps of the top and bottom of the model were generated. The results of the porosity measurements were assigned to the previously separated lithological types of rocks. The distribution of porosity at the

Autor do korespondencji: T. Kwilosz, e-mail: tadeusz.kwilosz@inig.pl

Artykuł nadesłano do Redakcji: 03.12.2019 r. Zatwierdzono do druku: 24.03.2020 r. 
grid points of the deposit model was determined for each type of rock and using both kriging methods. The cross-validation method was used to assess the uncertainty of the results. Finally, the effective pore volume of the deposit model was calculated, assuming that only sandstone and mudstone rocks are sources of the effective pores. The uncertainty of the analysis was estimated. Real data from geophysical measurements for the Miocene gas field were used for the study.

Key words: kriging, cross-validation, effective porosity.

\section{Wstęp}

W związku ze zmniejszającymi się zasobami gazu w złożach zlokalizowanych w utworach piaskowcowych i skałach węglanowych coraz większym zainteresowaniem cieszą się struktury geologiczne piaskowcowo-mułowcowo-łupkowe ulokowane w utworach miocenu (Bromowicz et al., 2001; Dusza et al., 2004; Dziadzio et al., 2006; Miziołek, 2014; Miziołek et al., 2017). Złoża te charakteryzują się dużą zmiennością facjalną tych utworów, w tym wyklinowaniem się lamin i warstewek (Karnkowski, 1997; Myśliwiec, 2004;Oszczypko, 2006; Wasilewska i Mucha, 2006; Żelaźniewicz et al., 2011; Sowiżdżał et al., 2014; Jędrzejowska-Tyczkowska, 2017). Założono, że niejednorodności litologiczne uwidocznią się na wykresach histogramów w formie rozkładów wielomodalnych lub wyraźnych zmian monotoniczności. Dane te posłużyły do wygenerowania przestrzennych rozkładów parametrów na siatce modelu w punktach nieobjętych pomiarem (Sinclair i Blackwell, 2002; Ringrose, 2008; Singh et al., 2013; Clark, 1986; Chiles i Delfiner, 1999; Mucha i Wasilewska, 2006).

\section{Analiza statystycznych rozkładów pomiarów gamma w odwiertach}

W celu wydzielenia podzbiorów danych przyporządkowanych skałom piaskowcowym, mułowcowym i łupkowym - z pomiarów profilowania gamma w każdym z odwiertów wykonano histogramy. Założono, że wyniki pomiarów gamma dokonanych dla trzech typów skał o różnej litologii zaznaczą się na wykresach histogramów w postaci rozkładów wielomodalnych. Przyjęto, że skały piaskowcowe są źródłem pomiaru gamma o najmniejszych wartościach, a skały łupkowe - o największych. Skały mułowcowe generują sygnał gamma o wartościach pośrednich. Taki efekt zaobserwowano na wykresach dla odwiertów: O-1, O-2, O-3, O-6, O-7, O-8, O-13, O-21, O-22 i O-25. Niestety, w przypadku kilku odwiertów nie stwierdzono takiej tendencji. Wówczas granicę rozdziału wyznaczono w miejscach wyraźnej zmiany tempa zmienności linii na wykresie. Dotyczy to sytuacji w odwiertach: O-9, O-10, O-11, O-12, O-15, O-23, O-27 i O-28.
Należy zaznaczyć, że taka metoda rozdziału danych na podzbiory nie jest do końca precyzyjna. W dużej mierze zależy od decyzji osoby interpretującej wyniki. Przykład wykresu wariogramu eksperymentalnego zamieszczono na rysunku 1.

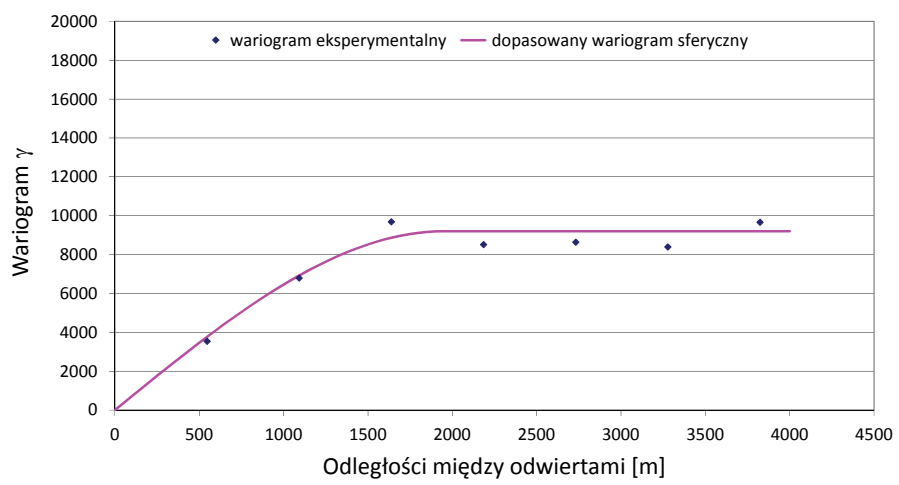

Rys. 1. Wariogram poziomy - głębokość stropu

Fig. 1. Horizontal variogram - depth to top of interval

Tabela 1. Procentowy udział miąższości każdej ze skał w miąższości całkowitej odwiertu i graniczne wartości sygnału pomiaru gamma, GR

Table 1. Percentage share of the thickness of each rock in the total thickness of the well and the limit values of the gamma measurement signal, GR

\begin{tabular}{|c|c|c|c|c|c|c|}
\hline \multirow{2}{*}{ Odwiert } & \multicolumn{3}{|c|}{$\begin{array}{c}\text { Procentowy udzial } \\
\text { w miąższości }\end{array}$} & \multicolumn{3}{c|}{$\begin{array}{c}\text { Granice wartości pomiaru } \\
\text { gamma, GR }\end{array}$} \\
\cline { 2 - 7 } & \multicolumn{3}{|c|}{ [\%] } & \multicolumn{3}{c|}{ [API] } \\
\cline { 2 - 7 } & piaskowce & mułowce & lupki & piaskowce & mulowce & lupki \\
\hline \hline O-1 & 29,9 & 50,3 & 19,8 & 64,5 & 73,5 & 88,935 \\
\hline O-2 & 14,1 & 53,3 & 32,6 & 64,1 & 72,6 & 89,052 \\
\hline O-3 & 14,3 & 74,1 & 11,6 & 62,4 & 81,9 & 93,333 \\
\hline O-4 & 18,1 & 74,5 & 7,4 & 75,4 & 89,9 & 116,615 \\
\hline O-6 & 26,8 & 52,1 & 21,1 & 67,5 & 77,0 & 92,298 \\
\hline O-7 & 18,2 & 72,6 & 9,1 & 66,3 & 81,9 & 91,378 \\
\hline O-8 & 4,0 & 58,8 & 37,3 & 55,2 & 73,5 & 96,131 \\
\hline O-10 & 6,6 & 90,2 & 3,2 & 65,2 & 86,9 & 103,583 \\
\hline O-11 & 3,4 & 90,7 & 5,8 & 58,8 & 81,2 & 93,797 \\
\hline O-12 & 17,3 & 64,1 & 18,7 & 65,4 & 79,1 & 99,395 \\
\hline O-13 & 12,3 & 73,3 & 14,4 & 72,5 & 85,6 & 100,625 \\
\hline O-15 & 26,4 & 64,4 & 9,2 & 74,2 & 84,0 & 92,801 \\
\hline O-21 & 18,5 & 46,8 & 34,7 & 69,3 & 80,8 & 92,753 \\
\hline O-23 & 16,5 & 66,2 & 17,3 & 59,9 & 75,8 & 88,341 \\
\hline O-25 & 10,4 & 55,6 & 34,0 & 67,6 & 77,9 & 96,335 \\
\hline O-26 & 15,8 & 75,5 & 8,7 & 70,0 & 84,0 & 100,208 \\
\hline O-27 & 13,6 & 82,0 & 4,4 & 71,9 & 88,7 & 98,054 \\
\hline O-28 & 8,1 & 87,1 & 4,8 & 72,6 & 87,8 & 92,364 \\
\hline
\end{tabular}


Zgodnie z regułami sztuki zwykle przyjmuje się, że histogramy obrazuje się w postaci wykresów słupkowych. W prezentowanej pracy przyjęto formę wykresów liniowych (łamana), aby lepiej zaobserwować i zobrazować zmienność wyników. Ponieważ każdy pomiar gamma w odwiercie wykonany był regularnie co $25 \mathrm{~cm}$ w całym zakresie miąższości, na podstawie wcześniej wykonanej analizy wyznaczono procentowy udział miąższości każdej ze skał w miąższości całkowitej dla danego odwiertu oraz graniczne wartości sygnału gamma dla danych typów skał (tab. 1).

\section{Generowanie przestrzennych rozkładów parametrów i model złoża}

\section{Model ztoża}

Wykorzystując rzeczywiste dane ze złoża gazowego zlokalizowanego w utworach miocenu, skonstruowano model o kształcie prostokąta podzielony na bloki o rozmiarach $50 \times 50 \mathrm{~m}$. Liczba bloków w kierunku W-E wynosi 78, a w kierunku N-S wynosi 29. W obrębie modelu zlokalizowano 18 odwiertów. Na etapie generowania rozkładów: procentowego udziału miąższości oraz średnich porowatości dla piaskowców, mułowców, łupków, jak również głębokości zalegania stropu i spągu rozkłady te mają wymiar płaski. Z tego względu trzeci wymiar modelu odzwierciedlający miąższość będzie zaniedbany. Miąższość efektywna poszczególnych bloków modelu dla każdej skały, wyznaczona na postawie rozkładu miąższości całkowitej i wyliczonych wartości procentowych udziałów miąższości dla wydzielonych skał, zostanie wykorzystana do wyliczenia objętości porów efektywnych dla modelu złoża.

\section{Analiza wariograficzna}

W celu rozpoznania przestrzennej struktury danych użyto analizy wariograficznej (Journel i Huijbregts, 1978; Deutsch, 2002). Podstawowym narzędziem służącym do analizy przestrzennej struktury danych jest wariogram. Wartości wariogramu wyrażają statystyczną zmienność przestrzennej zmiennej losowej $Z(x, y)$ odpowiadającej danym pomiarowym (procentowych udziałów miąższości, porowatości oraz głębokości zalegania stropu i spągu złoża). Definicja wariogramu korzysta z założenia o lokalnej stacjonarności drugiego rzędu, $\mathrm{tj}$.:

- wartość oczekiwana zmiennej $Z$ nie zależy od położenia $E[Z(x, y)]=$ const;

- wariancja zmiennej $[Z(x+d x, y+d y)-Z(x, y)]$ jest skończona i zależy jedynie od wielkości $(d x, d y)$ :

$$
\operatorname{var}[Z(x+d x, y+d y)-Z(x, y)]=2 \gamma(h),
$$

gdzie: $h$-długość wektora $[d x, d y]$.

Te wielkości rozkładu przestrzennej zmiennej $Z$ definiują wariogram eksperymentalny (1).

$$
\gamma(h)=1 / 2 E\left[(Z(x+d x, y+d y)-Z(x, y))^{2}\right]
$$

Na podstawie serii danych pomiarowych dokonuje się dopasowania wariogramu teoretycznego do wariogramu eksperymentalnego. Na użytek tej pracy wykorzystano pojedynczy model sferyczny opisany wzorem (2):

$$
\gamma(r)=\left\{\begin{array}{lll}
b & \frac{3}{2} \frac{r}{a} & \left.-\frac{1}{2}\left(\frac{r}{a}\right)^{3}\right] \\
b & \text { dla } & r \leq a \\
\text { dla } & r>a
\end{array}\right\}
$$

Przykładowy wynik jednego z wariogramów zaprezentowano na rysunku 2 oraz w tabeli 2.

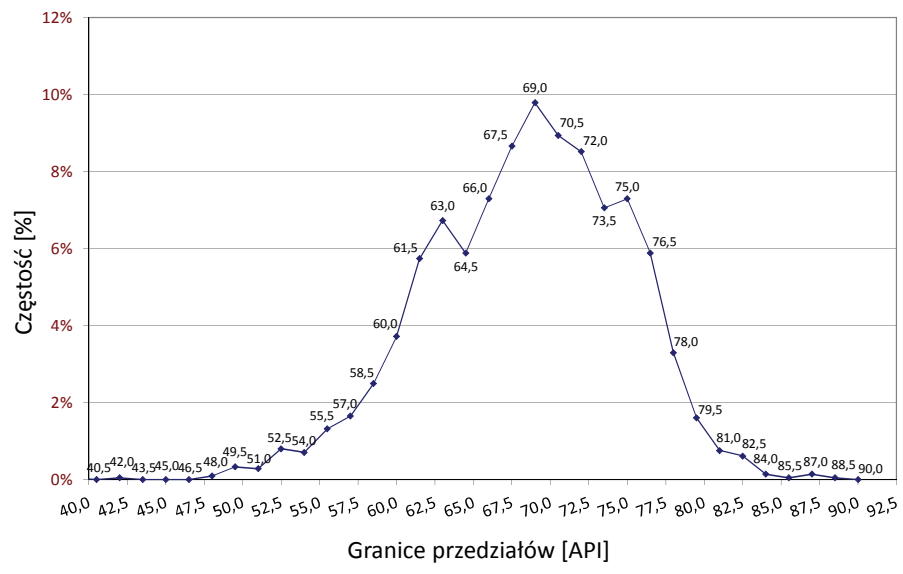

Rys. 2. Histogram dla pomiaru gamma w odwiercie O-1

Fig. 2. Histogram for the gamma ray $\log$ in the well O-1

Tabela 2. Parametry wariogramów teoretycznych dla badanych parametrów

Table 2. Parameters of theoretical variograms for the parameters tested

\begin{tabular}{|l|c|c|c|}
\hline \multirow{2}{*}{\multicolumn{1}{|c|}{ Parametr }} & \multicolumn{3}{c|}{$\begin{array}{c}\text { Parametry wariogramu } \\
\text { teoretycznego }\end{array}$} \\
\cline { 2 - 4 } & a & b & c \\
\cline { 2 - 4 } & {$[\mathrm{m}]$} & & \\
\hline \hline Procent miąższości piaskowców & 640 & 0,0058 & 0 \\
\hline Procent miąższości mułowców & 1000 & 0,019 & 0 \\
\hline Procent miąższości łupków & 1010 & 0,0145 & 0 \\
\hline Głębokość stropu & 1950 & 9200 & 0 \\
\hline Głębokość spągu & 2500 & 14000 & 0 \\
\hline Porowatość piaskowców & 1250 & 8,5 & 0 \\
\hline Porowatość mułowców & 1300 & 3,8 & 0 \\
\hline
\end{tabular}




\section{Przestrzenne rozkłady badanych parametrów}

W celu wygenerowania przestrzennych rozkładów badanych parametrów użyto metody krigingu zwykłego oraz krigingu $z$ trendem. Pomimo wszystkich wad tych metod związanych $z$ efektem wygładzania, polegającym na przeszacowaniu niskich i niedoszacowaniu wysokich wartości parametrów w węzłach sieci interpolacyjnej, należy jednak uznać, że są to metody opierające się na założeniu minimalizacji estymatora $\sigma^{2}(x)$ przy respektowaniu warunku nieobciążenia estymatora (Wasilewska i Mucha, 2006; Szott, 2008). Ponadto są to metody znane i akceptowane w przemyśle oraz łatwe do zaprogramowania i tym samym pełnej kontroli. Pomimo dobrze znanego (wielu czytelnikom) i często opisywanego modelu matematycznego tych metod warto je przytoczyć (przypomnieć) - chociażby w celach edukacyjnych (Kwilosz et al., 2003; Szott, 2010; Sowiżdżał, 2013).

Kriging jest metodą liniowej interpolacji ważonej pomiędzy danymi kontrolnymi (wartościami parametru w odwiertach), której wagi spełniają warunek minimalizacji błędu interpolacyjnego. Niech $\left\{\left(x_{i}, y_{i}\right)\right\}_{i=1, \ldots, N}=\{r\}_{i=1, \ldots, N}$ oznacza współrzędne $N$ punktów (odwiertów) na złożu, w których znane są wartości parametrów i niech $\{Z\}_{i=1, \ldots, N}$ oznacza te wartości. Wówczas uwzględniając niezależny trend (jeśli istnieje), można określić składową (residuum) $Z_{\text {res }}$ będącą częścią (rozkładu parametru) podlegającą opisowi geostatystycznemu (3):

$$
\left(Z_{\text {res }}\right)_{i}=(Z)_{i}-\left(Z_{\text {trend }}\right)_{i}
$$

gdzie: $Z_{\text {trend }}$ - składowa pochodząca od trendu.

Niech wymieniony rozkład opisany jest wariogramem $\gamma(\boldsymbol{r})$. Wówczas wartość parametru $Z_{\text {res }}\left(\boldsymbol{r}_{\mathbf{0}}\right) \mathrm{w}$ dowolnym punkcie $\boldsymbol{r}_{\mathbf{0}}$ pochodząca od rozkładu statystycznego wyraża się wzorem (4):

$$
Z_{\text {res }}\left(r_{0}\right)=\sum_{i=1}^{N} \lambda_{i}\left(r_{0}\right)\left(Z_{\text {res }}\right)_{i}
$$

gdzie: $\lambda_{i}$ jest rozwiązaniem układu $N+1$ równań (5)

$$
(A)(\lambda)=\left(\gamma_{0}\right)
$$

gdzie:

$(A)$ - oznacza macierz $(N+1) \times(N+1)$ elementów taką, że:

$(A)_{i i}=0$ $i=1, \ldots, N+1$

$(A)_{i j}=\gamma\left(\boldsymbol{r}_{\boldsymbol{i}}-\boldsymbol{r}_{\boldsymbol{j}}\right) \quad i \neq j \quad \mathrm{i} j=1, \ldots, N$

$(A)_{N+1, i}=(A)_{i, N+1}=1 \quad i=1, \ldots, N$

$\left(\gamma_{0}\right)$ - oznacza $N+1$-elementowy wektor stałych:

$\left(\gamma_{0}\right)_{i}=\gamma\left(\boldsymbol{r}_{\mathbf{0}}-\boldsymbol{r}_{\boldsymbol{i}}\right) \quad i=1, \ldots, N$
$\left(\gamma_{0}\right)_{N+1}=1$

( $\lambda)$ - oznacza $N+1$-elementowy wektor rozwiązań $\lambda_{i}\left(\boldsymbol{r}_{\mathbf{0}}\right)$ :

$(\lambda)_{i}=\lambda_{i}\left(\boldsymbol{r}_{\mathbf{0}}\right) \quad$ dla $i=1, \ldots, N$

$(\lambda)_{n+1}=\mu$-dodatkowa niewiadoma (mnożnik Lagrange'a).

Wyliczając w bezpośredni sposób składową w punktach $\boldsymbol{r}_{\mathbf{0}}$ pochodzącą od trendu $Z_{\text {trend }}\left(\boldsymbol{r}_{\mathbf{0}}\right)$, znajdujemy całkowitą wartość parametru $Z\left(\boldsymbol{r}_{\mathbf{0}}\right)=Z_{\text {res }}\left(\boldsymbol{r}_{\mathbf{0}}\right)+Z_{\text {trend }}\left(\boldsymbol{r}_{\mathbf{0}}\right)$.

Z powyższego przedstawienia widać, jaka jest zależność generowanej wartości $Z$ od parametrów rozkładu. Zależność ta obejmuje:

- trend;

- parametry charakteryzujące wariogram $\gamma(\boldsymbol{r})$ (typowo 2-4 parametry);

- położenia punktów i wartości pomiarowe w tych punktach (traktowane jako wielkości znane i niezmienne).

Ponieważ kriging jest liniową kombinacją danych kontrolnych, to jego wyniki zachowują rozkład normalny, o ile dane te posiadają taką własność. Z tego właśnie powodu bierze się wymóg normalnego rozkładu analizowanych danych omawiany wcześniej.

\section{Realizacje przestrzennych rozkładów dla badanych parametrów}

Opierając się na wcześniej przygotowanych danych pomiarowych, parametrach wariogramów oraz parametrach siatki modelu, wygenerowano przestrzenne rozkłady dla:

- procentowych udziałów miąższości piaskowców w miąższości całkowitej;

- procentowych udziałów miąższości mułowców w miąższości całkowitej;

- procentowych udziałów miąższości łupków w miąższości całkowitej;

- głębokości zalegania stropu;

- głębokości zalegania spągu;

- średnich porowatości dla piaskowców;

- średnich porowatości dla mułowców.

Użyto obydwu metod interpolacyjnych. Średnie wartości porowatości (po stronie danych źródłowych) dostępne były tylko dla siedmiu odwiertów: O-2, O-6, O-7, O-13, O-26, O-27 i O-28. Uzyskane wyniki zaprezentowano w formie map rozkładów na rysunkach 3-9. W przypadku metody krigingu $\mathrm{z}$ trendem skorzystano $\mathrm{z}$ postaci trendu opisanego wielomianem (6):

$$
T(x, y)=a_{0}+a_{1} \cdot x+a_{2} \cdot y+a_{3} \cdot x^{2}+a_{4} \cdot x \cdot y+a_{5} \cdot y^{2}
$$

Wyliczone współczynniki trendu zamieszczono w tabeli 3. 


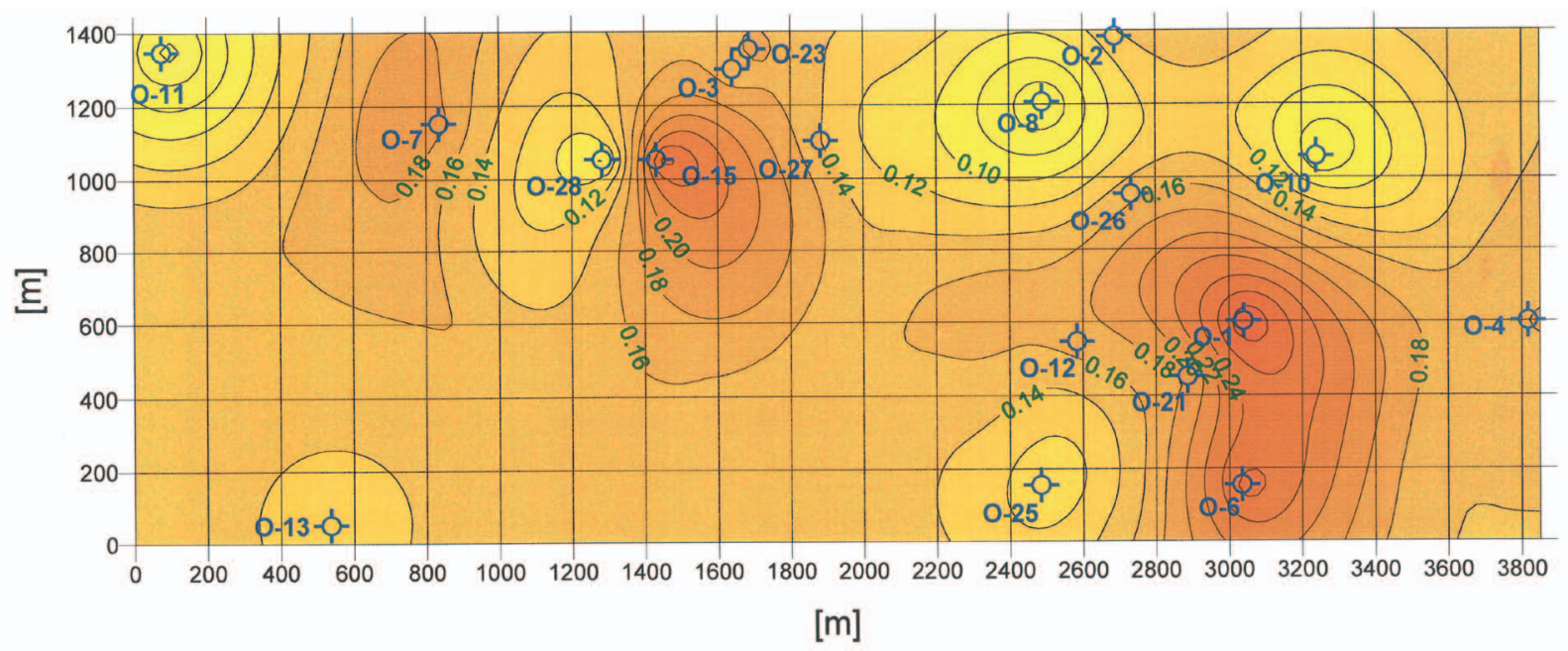

Rys. 3. Rozkład udziału piaskowców w miąższości całkowitej - kriging bez trendu

Fig. 3. Distribution of the share of sandstone in the total thickness - trendless kriging

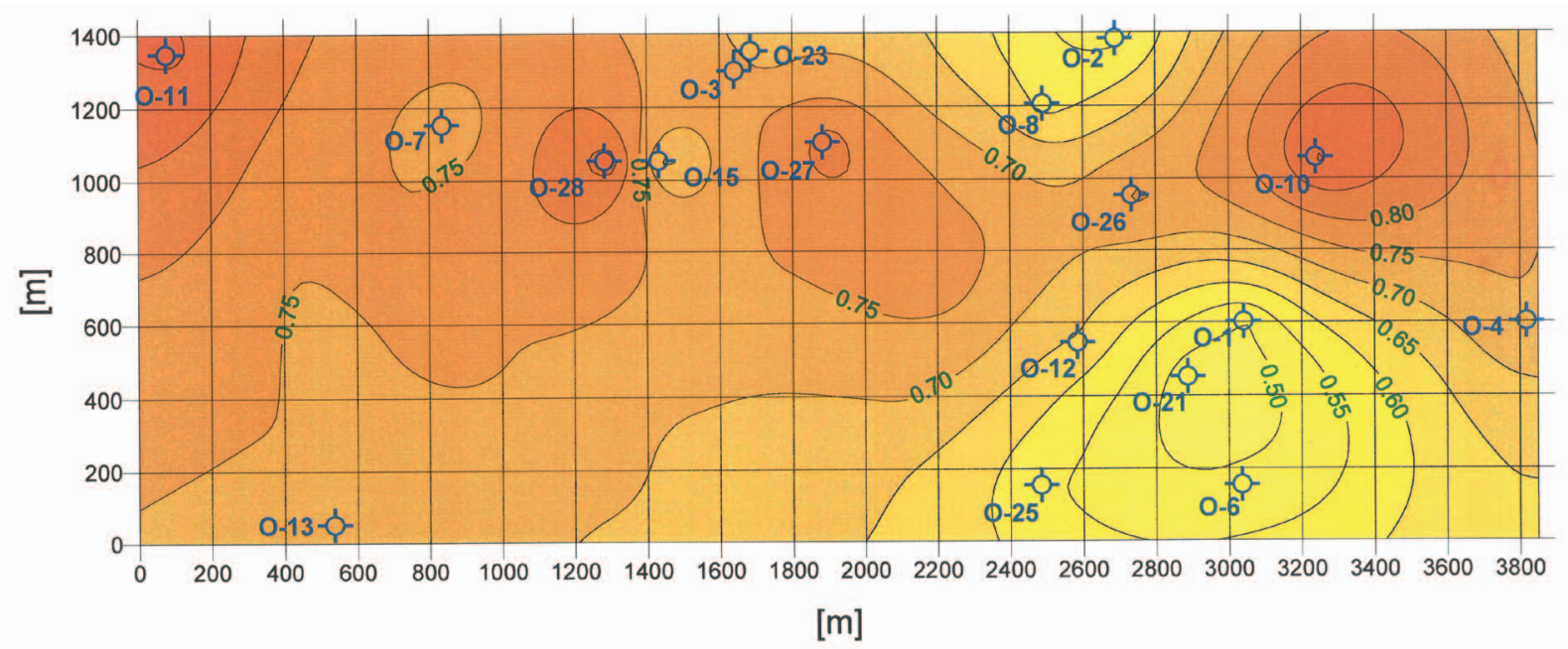

Rys. 4. Rozkład udziału mułowców w miąższości całkowitej - kriging bez trendu

Fig. 4. Distribution of the share of mudstone in the total thickness - trendless kriging

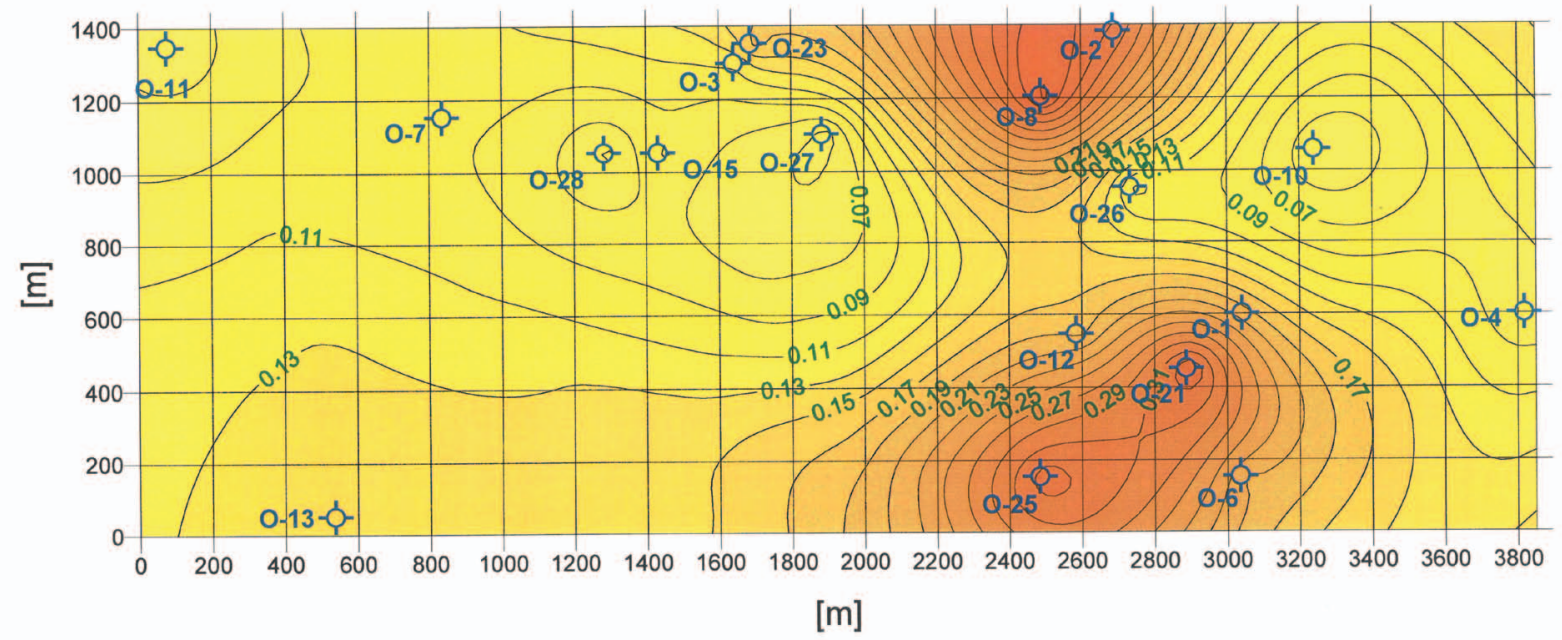

Rys. 5. Rozkład udziału łupków w miąższości całkowitej - kriging bez trendu

Fig. 5. Distribution of the share of shale in the total thickness - trendless kriging 


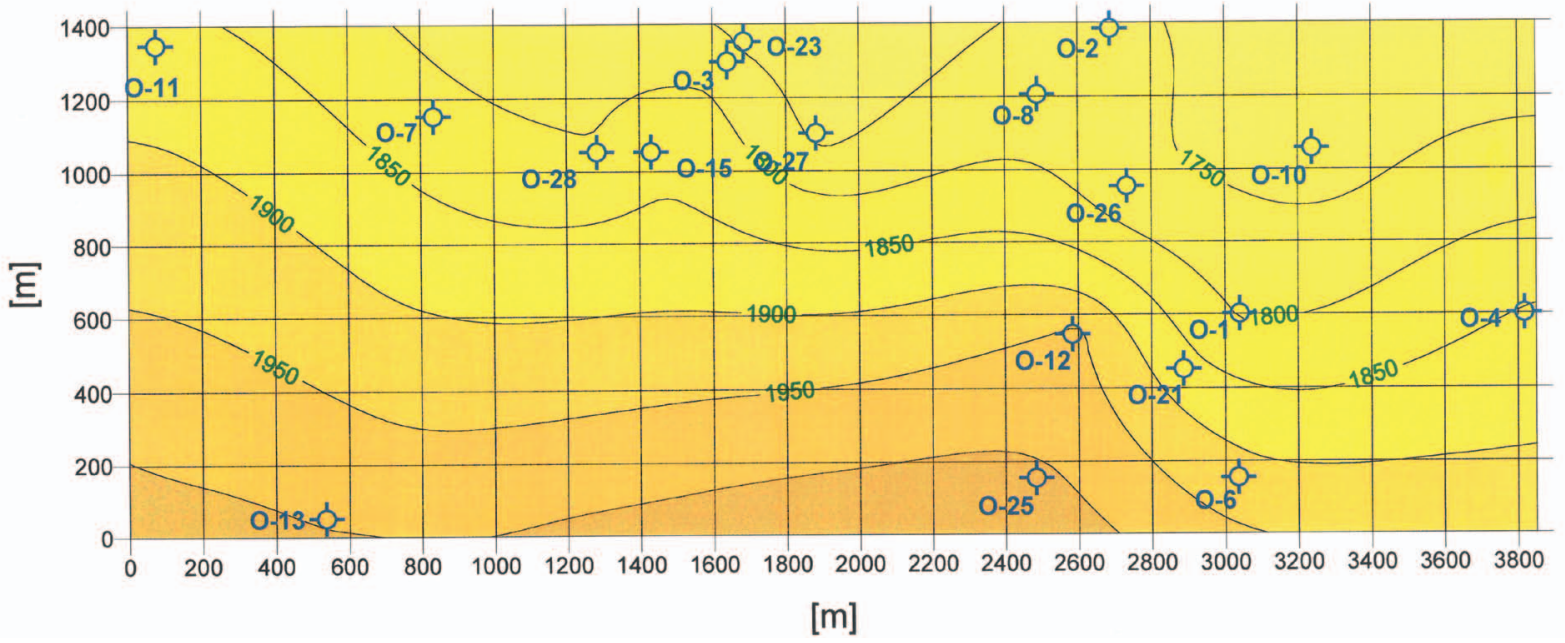

Rys. 6. Rozkład głębokości stropu [m p.p.t.] - kriging bez trendu

Fig. 6. Distribution of the depth to top of interval $[\mathrm{AGL}]$ - trendless kriging

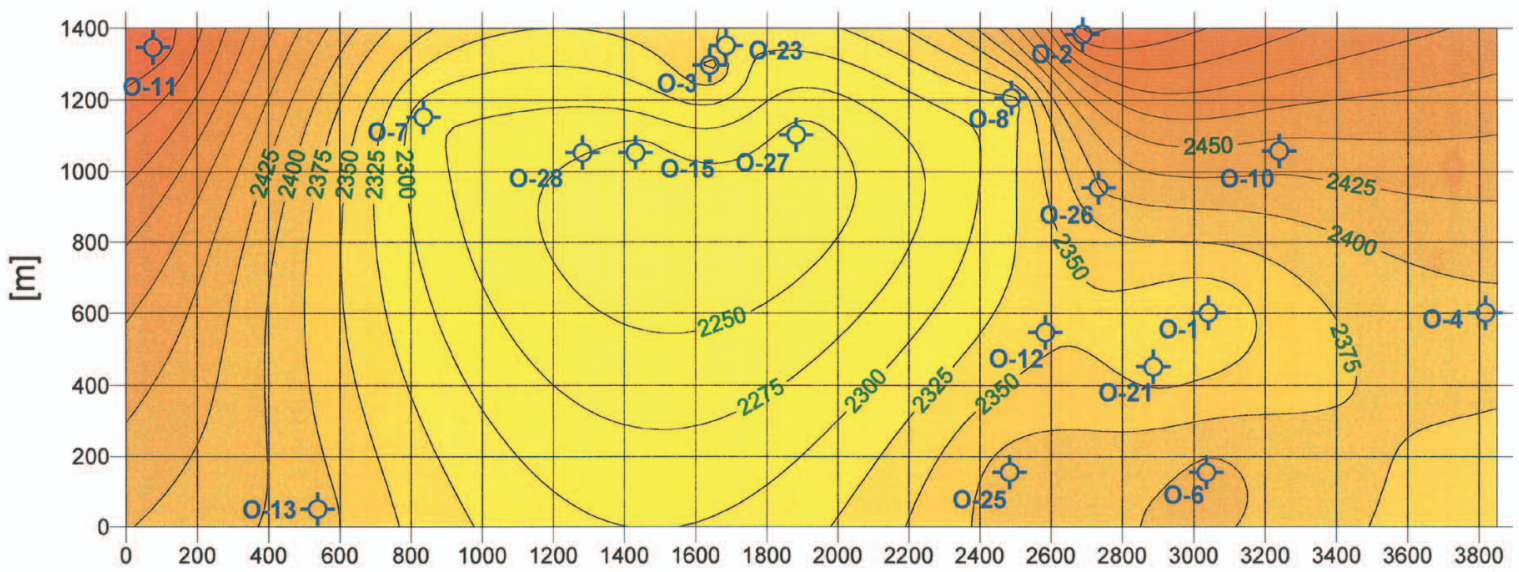

[m]

Rys. 7. Rozkład głębokości spągu [m p.p.t.] - kriging bez trendu

Fig. 7. Distribution of the depth to base of interval $[\mathrm{AGL}]$ - trendless kriging

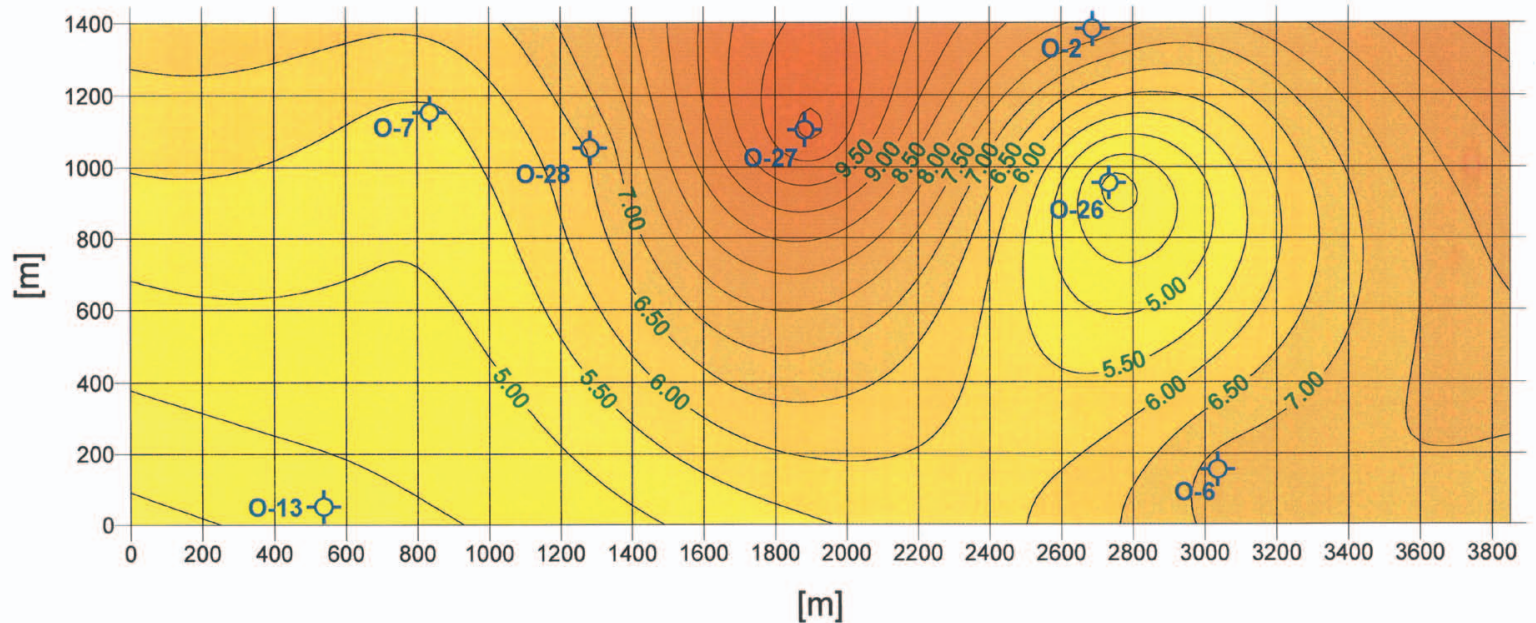

Rys. 8. Rozkład średniej porowatości piaskowców [\%] - kriging bez trendu

Fig. 8. Distribution of average sandstone porosity [\%] - trendless kriging 


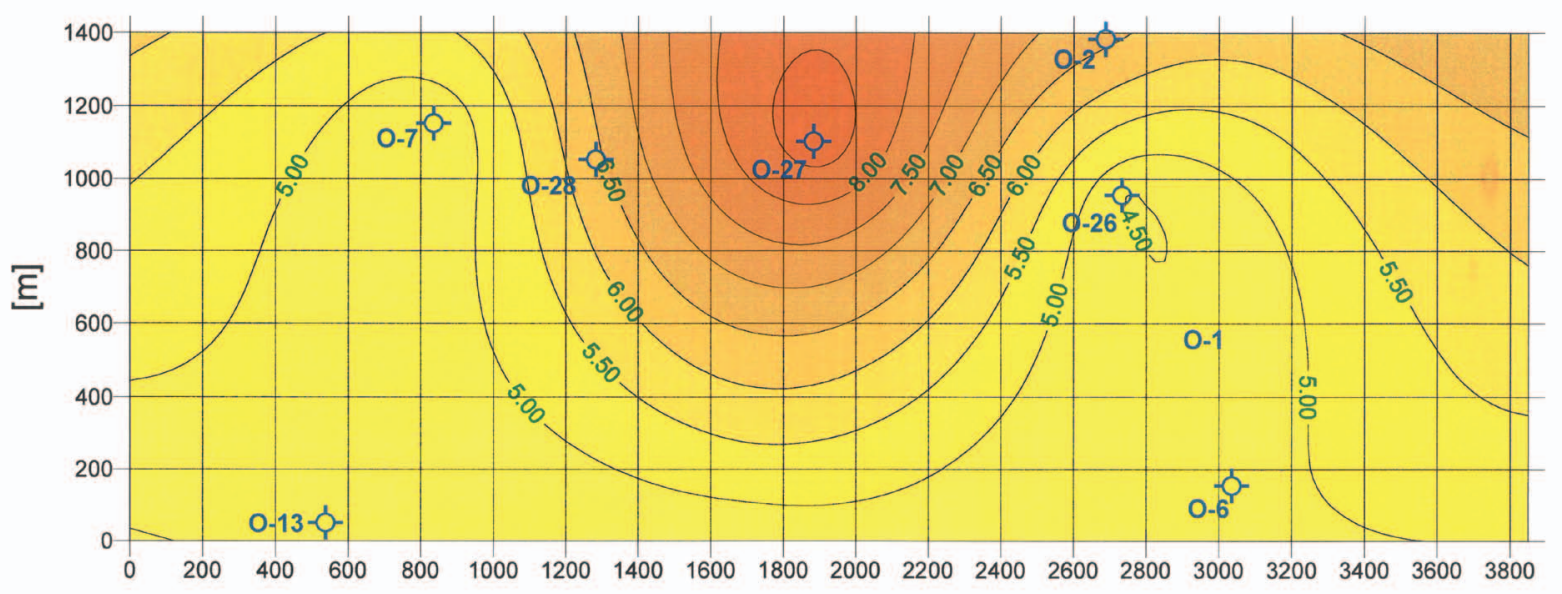

[m]

Rys. 9. Rozkład średniej porowatości mułowców [\%] - kriging bez trendu

Fig. 9. Distribution of average mudstone porosity [\%] - trendless kriging

Tabela 3. Współczynniki trendu dla szacowanych parametrów

Table 3. Trend coefficients for estimated parameters

\begin{tabular}{|l|c|c|c|c|c|c|}
\hline \multirow{2}{*}{\multicolumn{1}{c|}{ Parametr }} & \multicolumn{5}{c|}{ Współczynniki trendu } \\
\cline { 2 - 7 } & $a_{0}$ & $a_{1}$ & $a_{2}$ & $a_{3}$ & $a_{4}$ & $a_{5}$ \\
\hline \hline Procent miąższości piaskowców & 0,1667 & $1,9 \mathrm{E}-05$ & $1,6 \mathrm{E}-04$ & $-1,0 \mathrm{E}-08$ & $1,8 \mathrm{E}-08$ & $-2,0 \mathrm{E}-07$ \\
\hline Procent miąższości mułowców & 0,5973 & $1,1 \mathrm{E}-07$ & $2,0 \mathrm{E}-04$ & $1,3 \mathrm{E}-08$ & $-8,7 \mathrm{E}-08$ & $3,8 \mathrm{E}-08$ \\
\hline Procent miąższości łupków & 0,2293 & $1,8 \mathrm{E}-06$ & $-3,8 \mathrm{E}-04$ & $-9,4 \mathrm{E}-09$ & $7,3 \mathrm{E}-08$ & $1,7 \mathrm{E}-07$ \\
\hline Głębokość stropu & 2078 & $-6,7 \mathrm{E}-02$ & $-2,4 \mathrm{E}-01$ & $1,5 \mathrm{E}-05$ & $-2,7 \mathrm{E}-05$ & $6,8 \mathrm{E}-05$ \\
\hline Głębokość spągu & 2817 & $-3,6 \mathrm{E}-01$ & $-4,5 \mathrm{E}-01$ & $7,4 \mathrm{E}-05$ & $3,3 \mathrm{E}-05$ & $2,3 \mathrm{E}-04$ \\
\hline
\end{tabular}

\section{Walidacja poprawności metod interpolacyjnych - oszacowanie niepewności uzyskanych wyników}

\section{Metoda kroswalidacji}

Uzyskane wyniki przestrzennych rozkładów obarczone są niepewnością (Mucha i Wasilewska, 2009a, 2009b; Mucha i Wasilewska-Błaszczyk, 2010). Stopień poprawności modelu można ocenić, porównując wartości estymowane z rzeczywistymi (pochodzącymi z pomiarów). Można tego dokonać, dzieląc zbiór danych źródłowych (na przykład używając metody losowej) na dwa podzbiory. Pierwszy z nich wykorzystywany jest jako zbiór danych źródłowych (punktów pomiarowych), a drugi służy do porównania wartości źródłowych z odpowiadającymi im wartościami wyliczonymi. Metoda ta nazywana jest walidacją podzbiorem (jackknifing). Wadą tej metody jest to, że wymaga ona znacznej wielkości zbioru danych źródłowych, oraz fakt, że zmniejszając zbiór danych użytych do interpolacji, jednocześnie wpływamy na pogorszenie dokładności dopasowania modelu. Pewną modyfikacją tej metody jest tzw. kroswalidacja (cross-validation). Polega ona na:
- eliminowaniu jednego punktu pomiarowego;

- wykonaniu interpolacji na pozostałych punktach modelu;

- odnotowaniu różnicy pomiędzy wartością w punkcie źródłowym i interpolowanym;

- zwróceniu punktu pomiarowego do zbioru danych źródłowych i eliminowaniu kolejnego punktu.

Proces ten powtarza się dla wszystkich danych źródłowych i w efekcie otrzymuje się taką samą liczbę zarejestrowanych różnic. Wadą tej metody jest to, że te same dane używane są w kolejnych krokach do modelu i jego oceny. Zaletą jest natomiast to, że do generowania rozkładów używany jest cały zbiór danych źródłowych, co pozwala na wykorzystanie tej metody w przypadku zbiorów o małej liczebności.

Ze względu na to, że zbiory danych użytych do generowania rozkładów nie były liczne (18 odwiertów), zastosowano metodę kroswalidacji do oceny poprawności uzyskanych wyników. Dla obydwu metod (kriging zwykły i kriging z trendem) użyto tej metody do oceny rozkładów procentowych udziałów piaskowców, mułowców i łupków w miąższości całkowitej, rozkładów głębokości stropu i spągu. Ze względu na małą liczbę danych (dane z 7 odwiertów) procedury tej nie zastosowano 
Tabela 4. Pierwiastek średniego błędu kwadratowego RMSE

Table 4. Root Mean Square Error RMSE

\begin{tabular}{|l|c|c|}
\hline \multicolumn{1}{|c|}{ Parametr } & $\begin{array}{c}\text { RMSE } \\
\text { kriging bez trendu }\end{array}$ & $\begin{array}{c}\text { RMSE } \\
\text { kriging } \mathbf{z} \text { trendem }\end{array}$ \\
\hline \hline Procent udziału piaskowców $\Delta$ pi [\%] & 9,1 & 12,9 \\
\hline Procent udziału mułowców $\Delta \mathrm{mu}[\%]$ & 13,3 & 22,5 \\
\hline Procent udziału łupków $\Delta \nmid u[\%]$ & 9,9 & 13,7 \\
\hline Głębokość stropu $\Delta$ st $[\mathrm{m}]$ & 49,1 & 58,4 \\
\hline Głębokość spągu $\Delta$ sp $[\mathrm{m}]$ & 93,1 & 207,7 \\
\hline
\end{tabular}

Tabela 5. Wyniki oszacowania objętości porów efektywnych wraz z oceną niepewności

Table 5. Results of estimation of effective pore volume together with uncertainty assessment

\begin{tabular}{|c|c|c|}
\hline & Kriging bez trendu & Kriging $\mathrm{z}$ trendem \\
\hline Objętość porów dla piaskowców $\left[\mathrm{m}^{3}\right]$ & 26117291 & 33709490 \\
\hline Objętość porów dla mułowców [m³] & 110557779 & 99008107 \\
\hline Objętość porów efektywnych $\left[\mathrm{m}^{3}\right]$ & 136675070 & 132717597 \\
\hline Objętość wszystkich porów [m³] & 2710324393 & 2771918815 \\
\hline Błąd bezwzględny oszacowania dla piaskowców [m³] & 18627648 & 34588511 \\
\hline Błąd względny oszacowania dla piaskowców [\%] & 71,32 & 102,61 \\
\hline Błąd bezwzględny oszacowania dla piaskowców $\left[\mathrm{m}^{3}\right]$ & 30400348 & 66134465 \\
\hline Błąd względny oszacowania dla piaskowców [\%] & 27,50 & 66,80 \\
\hline Błąd względny oszacowania objętości porów efektywnych [\%] & 35,87 & 75,89 \\
\hline
\end{tabular}

do oceny rozkładów porowatości. Jako miary błędu (różnicy wartości zmierzonej i obliczonej) użyto pierwiastka średniego błędu kwadratowego RMSE (root mean squared error), gdyż ma on (7) wymiar mierzonego parametru i może być wykorzystany do obliczenia niepewności oszacowania objętości porów efektywnych w modelu złoża (Szott, 2006).

$$
R M S E=\sqrt{\sum_{i=1}^{n} \frac{\left(x_{i}-\hat{x}_{i}\right)^{2}}{n}}
$$

Otrzymane wyniki zamieszczono w tabeli 4.

Można zauważyć, że w przypadku metody interpolacyjnej krigingu zwykłego uzyskano lepsze wyniki dla wszystkich ocenianych rozkładów w porównaniu z metodą krigingu $\mathrm{z}$ trendem.

Na zakończenie obliczono objętość porów efektywnych modelu (10), zakładając tylko udział porów zidentyfikowanych w obrębie piaskowców (8) i mułowców (9).

$$
\begin{gathered}
V_{p, p o r}=\sum_{i=1}^{N \cdot M}\left(d_{x} \cdot d_{y} \cdot H_{c, i} \cdot h_{p, i} \cdot \varphi_{p, i}\right) \\
V_{m, p o r}=\sum_{i=1}^{N \times M}\left(d_{x} \cdot d_{y} \cdot H_{c, i} \cdot h_{m, i} \cdot \varphi_{m, i}\right)
\end{gathered}
$$

$$
V_{\text {por }}=V_{p, p o r}+V_{m, p o r}
$$

gdzie:

$V_{\text {por }}$ - objętość porów efektywnych modelu $\left[\mathrm{m}^{3}\right]$,

$V_{p, p o r}$ - objętość porów efektywnych piaskowców $\left[\mathrm{m}^{3}\right]$,

$V_{m, p o r}$ - objętość porów efektywnych mułowców $\left[\mathrm{m}^{3}\right]$,

$N \times M$ - liczba bloków modelu,

$d_{x}, d_{y}$ - rozmiary bloku [m],

$H_{c, i}$ - miąższość całkowita dla (i) bloku modelu [m],

$h_{p, i} h_{m, i}$ - procentowy udział miąższości piaskowców i mu-

łowców w miąższości całkowitej dla bloku $(i)$ [-],

$h_{p, i}, h_{m, i}-$ średnia porowatość piaskowców i mułowców dla

bloku $(i)[-]$.

Otrzymane wyniki zamieszczono w tabeli 5.

\section{Wnioski}

1. Oszacowanie objętości porów efektywnych w złożach piaskowcowo-mułowcowo-łupkowych ulokowanych w strukturach miocenu ze względu na ich specyficzną budowę nie jest zdaniem trywialnym i wymaga zastosowania metod dobranych do każdego analizowanego przypadku.

2. Zastosowanie metod zwykłego krigingu i krigingu z trendem może być obarczone dużym błędem dopasowania modelu do danych. 
3. W analizowanym przypadku metoda krigingu zwykłego obarczona była mniejszym błędem dopasowania modelu.

4. Oszacowanie niepewności dopasowania modelu jest kluczowym zadaniem w przypadku stosowania metod geostatystycznych, a metoda kroswalidacji jest właściwą propozycją.

Artykuł powstał na podstawie pracy statutowej pt.: Modelowanie geostatystyczne $w$ wyznaczaniu przestrzennego rozkładu parametrów petrofizycznych utworów ilasto-mułowcowych - praca INiG - PIB na zlecenie MNiSW; nr zlecenia: 0027/KP/2019, nr archiwalny: DK-4100-0027/2019.

\section{Literatura}

Bromowicz J., Kuśmierek J., Łapinkiewicz A.P., Maćkowski T., 2001. Geologiczna interpretacja zmienności parametrów petrofizycznych w obszarze wschodniej części Karpat polskich. [W:] Kuśmierek J. (red.), Charakterystyka parametrów petrofizycznych fliszowych serii ropogazonośnych Karpat polskich. Polish Journal of Mineral Resources, Towarzystwo Geosynoptyków „, Geos”, Kraków, 4: 31-77.

Chiles J.P., Delfiner P., 1999. Geostatistics. John Wiley, New York.

Clark I., 1986. The Art of Cross Validation in Geostatistical Applications. [W:] Ramani R.V. (ed.). $19^{\text {th }}$ Application of Computers and Operations Research in the Mineral Industry. Society of Mining Engineers, Littleton, Colorado.

Deutsch C.V., 2002. Geostatistical Reservoir Modeling. Oxford University Press.

Dusza R., Filar B., Miziołek M., 2004. Analiza litologiczno-facjalna utworów miocenu w rejonie PMG Husów. Prace Instytutu Nafty $i$ Gazu, 127. ISSN 0209-0724.

Dziadzio P., Maksym A., Olszewska B., 2006. Sedymentacja utworów miocenu we wschodniej części zapadliska przedkarpackiego. Przeglad Geologiczny, 54(5): 413-419.

Jędrzejowska-Tyczkowska H., 2017. Dobór optymalnej rozdzielczości sekcji sejsmicznej w drodze analizy i modyfikacji charakterystyk spektralnych danych sejsmiki powierzchniowej i otworowej. Nafta-Gaz, 8: 531-550. DOI: 10.18668/NG.2017.08.01.

Journel A.C., Huijbregts Ch.J., 1978. Mining Geostatistics. London Academic Press: 1-600.

Karnkowski P.H., 1997. Baseny sedymentacyjne a prowincje naftowe Polski - zarys problematyki. Przeglad Geologiczny, 45(10): 992-994.

Kwilosz T., Pańko A., Szott W., 2003. Zastosowanie metody geostatycznej analizy danych dla potrzeb symulacji modeli złóż węglowodorów. Prace Instytutu Górnictwa Naftowego i Gazownictwa, 126: $1-35$.

Miziołek M., 2014. Nowe oprogramowanie geologiczne do budowy przestrzennych modeli złóż. Nafta-Gaz, 6: 343-350.

Miziołek M., Filar B., Cierzniak M., 2017. Pułapki złożowe zapadliska przedkarpackiego w czołowej strefie nasunięcia Karpat. Nafta-Gaz, 8: 551-556. DOI: 10.18668/NG.2017.08.02.

Mucha J., Wasilewska M., 2006. Teoria opróbowania Gy i przykłady jej zastosowań w geologii górniczej w Polsce. Przegląd Górniczy, 12: 3-38.
Mucha J., Wasilewska M., 2009a. Ocena błędów opróbowania złóż - statystyczny niezbędnik geologa górniczego. Górnictwo Odkrywkowe, 2-3: 84-90.

Mucha J., Wasilewska M., 2009b. Trójwymiarowe modelowanie wartości parametrów złożowych metodą krigingu zwyczajnego 3D. Kwartalnik AGH Geologia, 3(2): 167-174.

Mucha J., Wasilewska-Błaszczyk M., 2010. Prognozowanie jakości urobku metodami geostatystyki 3D - perspektywy i ograniczenia. Gospodarka Surowcami Mineralnymi, 26(2): 57-67.

Myśliwiec M., 2004. Mioceńskie skały zbiornikowe zapadliska przedkarpackiego. Przeglad Geologiczny, 52(7): 581-592.

Oszczypko N., 2006. Powstanie i rozwój polskiej części zapadliska przedkarpackiego. Przeglad Geologiczny, 54 (5): 396-402.

Ringrose P.S., 2008. Total-property modeling: Dispelling the netto-gross myth. SPE Reservoir Evaluation \& Engineering, 11(5): 866-873.

Sinclair A.J., Blackwell G.H., 2002. Applied Mineral Inventory Estimation. Cambridge University Press: 1-381.

Singh V., Yemez I., Sotomayor J., 2013. Key factors affecting 3D reservoir interpretation and modeling outcomes: Industry perspectives. British Journal of Applied Science \& Technology, 3(3): 376-405.

Sowiżdżał K., 2013. Analiza niepewności wyników obliczeń zasobów złóż węglowodorów metodą objętościową, w oparciu o statyczny, przestrzenny model złoża. Nafta-Gaz, 12: 934-941.

Sowiżdżał K., Stadtmüller M., Słota-Valim M., 2014. Modelowanie facjalne i parametryczne jako narzędzie analizy i integracji spektrum danych geologiczno-geofizycznych. Przeglad Geologiczny, 62(12): 818-824.

Szott W., 2006. Zastosowanie statystycznych metod projektowania eksperymentu do probabilistycznej oceny zasobów złóż węglowodorów. Prace Instytutu Nafty i Gazu, 138. ISSN 0209-0724.

Szott W., 2008. Analiza niepewności w prognozach eksploatacji złóż przy zastosowaniu modeli geostatystycznych. Prace Instytutu Nafty $i$ Gazu, 148. ISSN 0209-0724.

Szott W., 2010. Zastosowanie symulacji komputerowych do modelowania pracy podziemnych magazynów gazu w Polsce. NaftaGaz, 5: 339-344.

Wasilewska M., Mucha J., 2006. Korekta efektu wygładzenia w procedurze interpolacyjnej krigingu zwyczajnego. Przeglą Górniczy, 1: 31-36.

Żelaźniewicz A., Aleksandrowski P., Buła Z., Karnkowski P.H., Konon A., Oszczypko N., Ślączka A., Żaba J., Żytko K., 2011. Regionalizacja tektoniczna Polski. Komitet Nauk Geologicznych PAN Wrocław: 1-60.

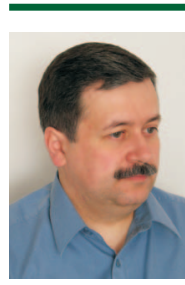

Dr Tadeusz KWILOSZ

Adiunkt w Zakładzie Podziemnego

Magazynowania Gazu

Instytut Nafty i Gazu - Państwowy Instytut Badawczy

ul. Lubicz 25 A

31-503 Kraków

E-mail: tadeusz.kwilosz@inig.pl 